\title{
SCENES OF COMMITMENT
}

\author{
BHARAT JAYRAM VENKAT \\ University of Oregon \\ (D) http: / / orcid.org/0000-0002-5246-9586
}

On a late spring morning in 2011, a middle-aged man with a respectable head of gray waited patiently in the hallway of a private clinic in Chennai, the capital city of the South Indian state of Tamil Nadu. This man, whom I will call Vasudevan, had for many years been committed to therapy, unfailingly consuming the medications that made it possible for him to live with HIV. ${ }^{1}$ For many of the clinic's staff, Vasudevan had been an ideal patient, in stark contrast to those who came to the hospital only in moments of desperation, long after their drug supplies had been exhausted. That morning, he had been among the first to arrive at the clinic, so he would be among the first to be seen by the doctors. His appointments tended to run like clockwork.

On this particular morning, however, things did not go as expected. He no longer wished to take his medication. To the contrary, Vasudevan asked to die. A commitment to his daughter, specifically, to successfully arrange her marriage, had thrown into question Vasudevan's commitment to a therapeutically sustained life. For many of the people I met at the clinic, the commitments that arose in relation to being a family member and to being a patient were congruent enough so as not to pose a conflict. Vasudevan, however, arrived at the clinic that day convinced that his commitments to his daughter and to his survival were intractably opposed. Such intractability demanded a response from the clinic's staff. In this and similar situations, I argue that the doctors and counselors at the clinic 
attempted to reconfigure the relationship between what were experienced as divergent or contradictory commitments in terms of what I call hierarchical subsumption. ${ }^{2}$ This mode of response worked not simply to recast treatment as noncontradictory with familial obligations; rather, the commitment to therapy became hierarchically subsumed by and therefore necessary to the fulfillment of such kin-based commitments .

This essay contributes to recent efforts by anthropologists to rethink ethics from the grounds of situated, lived experiences. Of particular interest here is the scholarship that has been loosely organized under the rubric of ordinary ethics. As Michael Lambek $(2010,2)$ puts it, the ordinary refers to that which is "relatively tacit . . . and happen[s] without calling undue attention to itself." He contrasts this surreptitious register of ethical life against more explicitly ethical situations in which, for example, "the right thing to do is unknown or hotly contested." This way of delineating the ordinary makes good sense in the context of a well-founded anthropological emphasis on practice (as a domain distinct from explicit knowledge or belief) and a desire to locate ethics as immanent to everyday life.

Yet this programmatic focus on the tacit threatens to obscure those forms of ethical reasoning that are employed in everyday life. It cannot be assumed that the clash of commitments only occurs outside of everyday life, as in those moments of "moral breakdown" described by Jarrett Zigon (2007). In particular, when everyday life itself becomes precarious, it should come as no surprise that questions of ethics, survival, and kinship become bound up with the ordinary. Here, I draw on the insights of Stefania Pandolfo (2007), who describes the forms of ethical disputation engaged in by two young men pondering the dangerous migration to Europe from Morocco. In these debates, what was at stake was not obvious or given in advance, but rather emerged through ethico-theological reasoning in an everyday marked by existential threat.

In thinking through the place of reasoning in ethical life, the work of Webb Keane proves particularly illuminating. In his contribution to Lambek's volume on ordinary ethics, Keane $(2010,82)$ insists that "ethics are not only tacit competences." He makes clear that certain circumstances call for what he describes as "explicit deliberation and justification" (Keane 2010, 69). One kind of circumstance in which ethical reasoning emerges might be productively conceived of in terms of ethical complexity, a concept developed by James Faubion $(2011,14)$ to denote situations in which one is subject to "two or more ethical commissions." In the clinic, one was regularly called on as family member and as patient. As I 
detail below, ethical reasoning about what it might mean to fulfill a commitment proved critical to understanding how the relationship between any given commitment and other commitments might be configured. ${ }^{5}$ Prior to asking, for example, whether a man might simultaneously take care of his daughter while adhering to a strict therapeutic regimen, the people that I met in the clinic grappled with the question of what precisely a man must do to take care of his daughter. Building on the work of Keane and Faubion, I suggest that when two recognizable commitments are felt to be incommensurable — when, for example, caring for one's daughter and taking medication are not obviously congruentthe ethical might take on a more explicit appearance in everyday life.

In this essay, I focus in particular on a shape that ethical reasoning might assume to evade the impasse formed at the crux of potentially contending commitments. I follow the lead of Signe Howell (1997), who argues for a shift away from simply analyzing the content of moral discourse. Howell (1997, 13-14; emphasis added) instead asks "what kind of reasoning a person (or a group of people) conducts in order to justify a particular decision in a situation of a moral dilemma." Along these lines, Karen Sykes (2009, 173) develops the concepts of common-place and axiomatic forms of reasoning to describe the ways in which "people negotiate paradoxes in their daily lives." Both of these forms of reasoning, however, leave in place the tensions and contradictions between competing desires or obligations. By contrast, the style of ethical reasoning I describe in this essay works to refigure potentially contending commitments into a hierarchy of means and ends, such that one becomes necessary to the other.

In what follows, I begin by illustrating how the clinical encounter became a space of ethical reasoning about the relationship between kin-based and therapeutic commitments. I provide a brief history of how HIV has been governed in India, a story that in fact has its starting point in Chennai (then Madras), to show how the increased availability of antiretroviral treatment transformed HIV from a problem of law into one of adherence. In an effort to make lifelong therapy manageable, the staff at the clinic where I conducted my research framed treatment as a matter that might be domesticated into everyday routines and knowledges. Paradoxically, the submersion of HIV treatment into the everyday made possible the suspension of the ethical priority of therapy, and of biological survival itself. ${ }^{6}$ This suspension established the grounds for the articulation of other, kinbased commitments within the space of the clinic. ${ }^{7}$ While other anthropologists have also pointed to the tensions between therapy and familial obligations in South Asia (e.g., Cohen 2001; Pinto 2014; Das 2015), my goal in the following two 
sections is to attend to how such tensions are alleviated through a particular style of reasoning that works to render these commitments congruent.

In the second section, I trace the movement from ethical suspension to hierarchical subsumption by returning to Vasudevan, the man who requested his own death to end his therapy and fulfill his commitment to his daughter. In the course of his conversation with a counselor at the clinic, the relationship between commitments, as well as the proper means of fulfilling them, were called into question, open to the interpretive capacities of the patient, the clinical staff and the anthropologist. What was expected to be a routine checkup quickly became an ethical deliberation on the utility of life and death.

I conclude by turning to another patient, Sendhil, whose indefatigable silence posed a challenge for his physician and for his family. Rather than insisting on the ethical priority of the commitment to therapy, Sendhil's physician argued instead that therapy was a means for Sendhil to fulfill a commitment to his mother. Here again, therapeutically sustained life, as well as death in the absence of treatment, were conceived of in terms of how they might impact what was recognized to be a hierarchically superior commitment to a close family member. Both Sendhil's silence and Vasudevan's speech called on the clinic's staff to reason beyond the ethical primacy of therapy to consider the ways in which treatment-and survival — might be recruited into the fulfillment of other commitments.

\section{SUSPENSION INTO THE EVERYDAY}

Prior to 1986, there had been no reported cases of HIV in India. In that year, Suniti Solomon, a professor of microbiology at Madras Medical College, identified the condition among sex workers who had been detained in a government remand home. As in much of the world, HIV quickly devolved into a problem of law and moral order, prompting the intensification of surveillance, policing, and detention (Dube 2000). Soon, drugs were developed that could suppress viral replication. The United States Food and Drug Administration (FDA) approved the first such drug, AZT, in 1987, followed by a host of other drugs that, taken in combination, promised to transform a terminal diagnosis into a chronic condition.

The activism of patient-based groups and allied communities that spurred pharmaceutical industry and regulatory bodies into making new drugs available has been well documented. In India, however, treatment was available only through private means, and at exorbitant cost. It was not until 2004 that flexible patent laws, a growing generic pharmaceutical industry, and previously unimag- 
inable levels of international aid set the stage for mass antiretroviral provision (Mahajan 2008). The Indian National AIDS Control Organization began what many critics diagnosed as a fatally slow rollout of first-line treatment at a handful of public medical facilities scattered around the country.

Over time, the treatment-provision program was scaled up, buoyed by fears that HIV would spread: that so-called high-risk populations, like sex workers, men who have sex with men, truck drivers, and injection drug users would pose a biomoral risk to the broader population. ${ }^{8}$ At the same time, the growing availability of antiretrovirals in India fueled new anxieties about drug adherence. Within a normative epidemiological logic, the failure of patients to regularly take these medications was understood to be catalyzing the evolution and transmission of drug-resistant strains of the retrovirus. ${ }^{9}$ However, what was at stake in the commitment to lifelong therapy seemed to exceed this bifurcated logic of individual- and population-level risk. Rather, the value of therapy frequently came to be adjudicated in relation to potentially competing commitments to close kin.

In 2011, I began fieldwork in a small, private clinic in the city of Chennai. My work at the clinic constituted the final piece of a longer project on HIV that I had begun in 2006, two years after the creeping start of the government's antiretroviral treatment provision program. The clinic operated within the confines of a narrow building tucked away into a corner of a larger voluntary hospital inaugurated half a century earlier by Jawaharlal Nehru, India's first prime minister. The clinic's reputation drew patients from the farthest reaches of the trafficchoked city, as well as from surrounding parts of Tamil Nadu and even from neighboring states. Those who came to the clinic had been-or feared that they had been-infected with HIV.

Each morning, patients poured into the clinic, waiting to see doctors, counselors, and nurses, to receive a new batch of medications, or to learn their diagnosis. During my time in the clinic, many of the staff, but also the families of patients, expressed to me their fear that a patient would not be able to "cope" with a positive diagnosis: because they were too young or too old to handle it, because they lacked the education required to understand, because it would cause them "tension" and make the condition worse. Increased knowledge was not, it seemed, equated with increased therapeutic commitment.

At the same time, too little knowledge also posed a problem. One morning, while conducting rounds in the inpatient wards, we stopped at the bed of a dangerously gaunt woman who had previously been receiving treatment from either a private practitioner or a government hospital. When asked what medi- 
cations she had been taking, the woman reached for a plastic bag filled with pills of assorted size and color that she jangled in front of the doctors. What these pills were called, or what they treated, she could not say. Therapeutic commitment was understood to require just the right amount and type of information, conveyed in the proper register (cf. Brada 2013). Otherwise, as with the woman we spoke to that morning, the risk of nonadherence was too great.

As a counselor at the clinic, Prabhakar's job was to strike this balance. Prabhakar was in his early twenties, raw-boned and energetic, with prematurely thinning hair subdued by a close crop. Although Prabhakar lacked medical training, he had completed a degree in social work, making him an indispensable part of the clinic's functioning. Prabakhar admitted to me that he had known very little about HIV when he first came to the hospital as part of the practicum for his degree. After seeing the work, and witnessing the need firsthand, he had decided to stay on.

I spent many mornings with Prabhakar in his office as he counseled patients and their family members. Prabhakar's small space had a window facing out onto the troubling juxtaposition of a sprawling park and an ever-growing garbage heap. There was no fan, so the lone window provided the only solace from the heat. Hung on the wall was a calendar, a gift from a diagnostic laboratory. Each month featured men and women in lab coats, grinning at the camera while simultaneously managing to operate complex X-ray machinery.

When the flow of patients dried up, usually in the early afternoon, Prabhakar and I would steal away for strong, sweet filter coffee, served in paper cups that transmitted the heat directly into our fingertips. In this highly caffeinated state, Prabhakar and I would discuss the patients we had seen together, or we would talk about something else entirely: the Indian tennis star who occasionally played on his neighborhood soccer team, Prabhakar's visits to his parents' home in the southern region of the state, or the nuances of Tamil grammar. From Prabakhar, I also began learning the Tamil neologisms for biomedical terms. Immunity or immune system became noi ethirppu sakthi, literally, a power in opposition or resistance to disease (see also Van Hollen 2013). ${ }^{10}$

Back in his office, Prabhakar would explain to patients how HIV lessened this power. Before receiving testing, patients would meet with Prabhakar to learn what HIV was, how it migrated between bodies, how they might have contracted the virus, and how it could be treated. After the laboratory had finished analyzing the tests, Prabhakar would once again meet with patients to deliver the results. When a patient's test results came back positive, Prabhakar would deliver the 
news with the utmost pragmatism, emphasizing the importance of adhering to the therapeutic regimen. Every day. Morning and night. At exactly the same times. With each new patient, he repeated these words, a kind of passcode to the "kingdom of the sick," as Susan Sontag $(1990,3)$ put it. Adherence, in other words, was not a once-and-done proposition, but rather premised on an ongoing repetition, a commitment to a specific temporal patterning of everyday life.

Once a patient had been diagnosed, they were expected to visit the hospital regularly to have lab analyses run of their white blood cell and viral levels, to pick up medications, and to receive adherence counseling. The existence of counseling suggests that nonadherence was expected and therefore to be rebuffed. Indeed, counseling explicitly addressed obstacles to adherence and reminded patients of this therapeutic rhythm, morning and night.

When actually speaking with patients, however, Prabakhar worked hard to de-exceptionalize the commitment to therapy. He would compare HIV to diabetes, an increasingly common condition among Indians across socioeconomic strata: "If you have sugar, you have to take your medicines every day." Here, a perceived cause of diabetes - sarkkarai or sugar - comes to stand in for its perceived effect, the condition itself. "HIV is just like sugar," he continued. "You can live an absolutely normal life."

Prabhakar pivoted smoothly from metonymy to simile, drawing on the common reference point of a seemingly manageable disease like diabetes to make a claim for HIV's normalcy. He told me that this comparison made HIV easier to understand. But he also hoped that the comparison made a positive diagnosis easier to accept. It was precisely this movement from the register of the medical profession - HIV is a chronic disease - to a more ordinary register - HIV is like sugar - that was supposed to make knowledge of diagnosis both appropriate for and palatable to the patient. This was Prabhakar's way of providing just enough but not too much knowledge. Such knowledge, conveyed through the image of another disease whose treatment had been largely domesticated, worked to submerge the commitment to therapy into everyday life. ${ }^{11}$

But normalcy required more than drugs alone. Prabhakar would also remind patients to eat nutritious food, drink boiled water, and exercise regularly. These practices, he would add, were important for everyone, regardless of HIV status. In this generalizable injunction - do this; everyone should do this - HIV became normalized even further. Having HIV is like having sugar because you must take medications daily, but having HIV is also like living an ordinary life because you must drink boiled water. In this fashion, the clinical demand to commit to therapy 
was rendered unexceptional through a gradual widening of the public to which it was addressed.

I began to think of Prabhakar as preaching a gospel of temporal normalcy, a well-practiced form of disclosing a diagnosis by submerging it into the rhythms of everyday life, rather than framing it as a radical break. If you take your medicines every day, and at the right times, then both the activities of your life and your lifespan can be normal: this is the promise of antiretroviral drugs. It was not simply that the commitment to a specific therapeutic rhythm (morning and night) made possible a continuation or return to normalcy. Everyday life was itself reorganized to include this punctuated pharmaceutical cycle. Rather than simply representing a deviation from the norms of health, pathology (and treatment) generated its own norms that nonetheless hewed closely to what was recognized as ordinary (cf. Canguilhem 1989). According to Prabhakar, the norms pertaining to the management of HIV so closely resembled the norms established by more domesticated conditions that HIV itself became normal, "just like sugar." Yet, as I will discuss below, this submersion of therapeutic commitment into everyday life paradoxically generated the conditions under which the priority of therapy could itself be suspended as other commitments came to the fore.

\section{NOT THE USUAL INJECTION}

I return now to Vasudevan, who on the day of his visit was called to meet with Prabhakar before seeing the doctors. Vasudevan sat down in front of Prabhakar's desk and began to dab his forehead furiously with a crumpled handkerchief extracted from his shirt pocket.

On many days in the clinic, I would watch as doctors reprimanded patients about skipping doses and appointments. Vasudevan was never subject to such displays. His commitment to both the duration and discipline of therapeutic time had been beyond reproach. Over the course of many years, he never missed appointments and took his medications twice daily. Failure to adhere, to "comply" in an outmoded idiom that on occasion still found its way to the lips of the hospital staff, often resulted in easy labeling: noncompliant, nonadherent, defaulter. These terms partake of a strong juridical and sovereign undertone, suggesting a failure to fulfill one's obligations. Failure to adhere also raised questions of desire and will. "There's no point," I was told by numerous doctors in moments of exhaustion. "They don't want to get well." It is important to note here that Vasudevan was never spoken of in this manner. 
Vasudevan's medical file recorded his regularity through its relative narrowness: instead of the heterogeneous sheets of paper that indicated problems hospital admissions, treatment for opportunistic infections, and various other complications - Vasudevan had only the regular laboratory reports and clinical notes indicating that all was well. To my eye, Vasudevan bore none of the visible stigmata of HIV infection, not even a mild fatigue that might indicate something amiss. His thin file and his physical appearance suggested an unswerving commitment to therapeutic discipline. By such measures, Vasudevan wanted to get well — or at least stay well, the best that can be hoped for when a condition lacks cure.

Prabhakar began to run through his regular battery of questions. "Are you taking your tablets daily?" he asked. "Yes, morning and night," Vasudevan responded.

"Any physical problems, old or new?"

"No," Vasudevan replied.

This interview seemed destined to produce yet another innocuous sheet of paper fitted neatly into Vasudevan's patient record.

Prabhakar's pen raced across the page as he made all of the cursory marks in the file, indicating that there were no concerns. Putting down his pen and closing the file, Prabhakar looked up and asked Vasudevan if he had any other questions, concerns, or doubts (santhegam). Vasudevan dabbed his brow, clearly losing the battle against the indomitable heat.

"Yes, one question." He met Prabhakar's eyes with his own. "Can you," he asked, pausing for a moment, "give an injection to kill me?"12

I leaned forward slightly from my chair. I thought that I had heard incorrectly. But even Prabhakar - for me, a paragon of tranquility — was visibly startled. He quickly regained his composure and asked Vasudevan to repeat himself, but the question remained unchanged.

Prabhakar was initially dumbfounded by Vasudevan's request. What could possibly be wrong, he wondered aloud. After all, Vasudevan seemed incredibly healthy, with none of the signs or symptoms of illness. He was not suffering from any of the debilitating opportunistic infections or drug-related side effects that plagued many of the other patients who sat waiting outside the counselor's office. Vasudevan's laboratory results were consistently good. His white blood cell counts were high. The drugs were doing their job. What could be the reason for his strange appeal? 
The problem, explained Vasudevan, precisely related to his continuing good health. He knew that he was doing well. But to maintain the efficacy of his treatment, he had recently switched to a second-line regimen of anti-HIV drugs, substantially more expensive than his earlier first-line regimen. Like the drugs that constitute basic first-line therapy, second-line drugs were also available from Indian generic drug manufacturers. But even in generic form, these drugs remained prohibitively expensive.

Second-line drugs were dispensed without cost through the Indian National AIDS Control Program, but only by means of a very selective, time-consuming rationing process that involved repeated meetings by state-level boards composed of medical bureaucrats. This left many without access to free or affordable treatment. Many of those who were eventually approved for government-provisioned second-line therapy only received these medications after becoming seriously ill. Horror stories abounded of those who died while waiting.

Vasudevan purchased the drugs with his own money to circumvent these time-consuming and potentially lethal bureaucratic channels, but the high cost constituted a substantial drain on his government pension. That money, he lamented, should have gone to "settling his daughter": that is, arranging her marriage. Although dowry had been legislatively outlawed in 1961 by the Dowry Prohibition Act, such forms of exchange remain central to marriage arrangements in Tamil Nadu and throughout much of India. At the clinic, I heard from many patients that expectations of dowry had actually intensified in recent years: an effect of economic liberalization, the increased availability of a range of consumer goods and, in certain parts of the state, remittances from overseas employment. Families also feared that failing to provide an adequate dowry could provoke inlaws to harm their daughters (see Diamond-Smith, Luke, and McGarvey 2008). Dowry not only facilitated marriage but was also thought to provide at least a partial safeguard for one's daughter.

For Vasudevan, adherence therefore came at a very high cost. To be committed to this medicine for life - a life that, according to Prabhakar, could extend to a normal lifespan — was also to be tethered to a perpetual financial drain that undercut the possibility of successfully and safely marrying off his daughter. For Vasudevan, to remain committed to therapy was to be "given over" (Cohen 2013) to medicine; it meant having nothing left to invest (in starkly financial terms) in the marriage of his daughter. In contrast to dominant bioethical and epidemiological framings, in which nonadherence figures as the central concern and adherence the solution, here, adherence emerged as the very problem. 
In addition to his financial concerns, Vasudevan was also anxious that others might learn of his condition. He explained that he lived with his family in a small village near the town of Kanyakumari, at the southernmost tip of the subcontinent. He belonged to the large Brahmin community in his village, into which he wished to marry his daughter. He despaired that if other villagers were to discover his condition, his daughter's prospects for marriage would dwindle to nothing. Word would spread quickly to the other Brahmins of the village, and no one would marry a daughter into such a family. Although Vasudevan's illness did not pose a biological danger to his daughter, public knowledge of his illness, as well as the cost of treatment, threatened her future.

Prabhakar listened to Vasudevan's concerns. The clinic, usually organized around the priority of therapeutic commitment, had been opened up to the articulation of other kinds of concerns: of a father's obligation to his daughter, and of a Brahmin's relation to a community in which both dowry and affliction had particular moral consequences. As this other commitment, structured by ties of kinship and caste, materialized within the space of the clinic, the value of adherence, and of living on, were called into question. In Vasudevan's request for death, these commitments - to his daughter, and to his treatment-were presented as being at odds, as a zero-sum game. To commit to one was to commit without remainder, to leave no excess - in this case, in monetary terms - for the other.

After acknowledging Vasudevan's anxieties, Prabhakar offered a counterpoint. If Vasudevan were to die, if he were able to somehow safeguard the secret of his illness and redirect his financial resources to settling his daughter, who would remain alive to ensure that his daughter was properly settled? It was Vasudevan's duty as a father, Prabhakar maintained, to orchestrate his daughter's marriage and ensure that a suitable match was made for her. Although Vasudevan's wife was alive and had not been infected by the virus, both Prabhakar and Vasudevan seemed to implicitly agree that she could not fulfill this (arguably paternal) duty. Death might solve some problems - for example, the financial difficulties that remained unresolved in the discussion between Prabhakar and Vasudevanbut it would also mean that Vasudevan's daughter would be without a father. Here, the conversation became about what precisely might be required for Vasudevan to fulfill his commitment to his daughter. In Prabhakar's framing, Vasudevan's survival was necessary to fulfilling the very commitment that Vasudevan had feared could not be fulfilled without his death. 
Through this feat of ethical reasoning, Prabhakar sidestepped what for Vasudevan had been figured as an impasse in which he felt compelled to choose between commitments. Prabhakar proposed instead a reconfiguration of commitments in which adherence came to matter insofar as it would make possible the fulfillment of Vasudevan's obligation to marry off his daughter. Although his primary task in the clinic was to encourage treatment adherence, Prabhakar never suggested to Vasudevan that therapy should be afforded priority simply for the sake of survival. Rather, Prabhakar acceded to the primacy of Vasudevan's commitment to his daughter, while arguing that its fulfillment required the continuation of treatment. In the conversation between Vasudevan and Prabhakar, therapeutic adherence - and by extension, survival — had been subsumed under what was recognized as Vasudevan's hierarchically superior paternal commitment. Prabakhar managed to reverse the terms of Vasudevan's argument by insisting that he must not die for his daughter, but, on the contrary, must live for her.

Here, the ethnographic record on Tamil kinship proves instructive. We can see, for example, how reciprocal duties and claims figure prominently within Louis Dumont's (1986) classic structuralist ethnography of a Pramalai Kallar community. However, in her recent ethnography of Tamil marriage practices, Isabelle Clark-Decès (2014) offers a striking reassessment of Dumont. She finds that such normative duties (kadamai) and claims (urimai) regularly fail to be actualized. ${ }^{13}$ Nonetheless, they remain for her interlocutors critical points of orientation, elaboration, and in many cases, aspiration. Such duties and claims operate less like Kantian moral laws demanding universal acquiescence and more as norms that orient creative reordering and ethical ratiocination. Even with a shared sense of what was right or appropriate, how one might go about fulfilling commitments to close kin was no clear-cut matter.

Similarly, the ethical priority was clear for both Prabhakar and Vasudevan: not therapeutic adherence, but rather a father's commitment to his daughter. When Vasudevan arrived at the clinic, he expressed the relationship between these commitments in starkly opposed terms. In his meeting with Prabhakar, he spoke of paternal obligation, caste-based approbation, and limited financial resources. Rather than insisting on the priority of therapy, Prabhakar accepted the primacy of Vasudevan's commitment to his daughter. Their conversation developed around the practical and ethical means by which such a commitment might be fulfilled, whether through life or through death. By proposing that Vasudevan's continued commitment to therapy was necessary to marrying off his daughter, 
Prabhakar offered a way to reconfigure the relationship between commitments in terms of hierarchical subsumption rather than mutual opposition.

\section{SHE'LL NEVER RECOVER}

In addition to sitting with Prabhakar during his counseling sessions, I also spent time with various clinicians in the hospital, especially Dr. Vijay. Uniformly stern with his patients, Vijay would occasionally break into a toothy grin when talking about his newborn daughter. He reserved a more thoughtful expression for describing to me the latest discoveries that he had read about in the medical journals. In addition to his work at the clinic, Vijay worked night shifts at another hospital to cover his bills. Remarkably, he never seemed to tire, or at least never showed it.

As in the counselor's office, questions of kinship and survival emerged alongside concerns about therapeutic adherence. One morning, about six months after I had begun working at the hospital, a man hesitantly entered into Vijay's office, helped along by his brother and his elderly mother. The patient, whom I will call Sendhil, appeared to be in his mid- to late twenties, rail-thin, with clothes hanging loosely from his joints. Vijay sat at his desk, quickly scribbling down case notes from his previous consultation. He closed the folder and looked up at the new arrivals.

The three of them sat in the chairs against the wall, to the side of Vijay's desk, Sendhil sandwiched uneasily in the center. I had vacated my usual seat and taken up a position at the edge of the examining table, greeting Sendhil and his family while trying not to knock over the stack of medical records piled high next to me.

Sendhil's mother and brother wore doleful expressions on their faces. They took turns explaining that Sendhil had not been sleeping, and that he had not taken his medications in fourteen days. Sendhil slouched down in his chair, fixing his gaze on the opposite wall.

After listening to their worries, Vijay quietly asked Sendhil's mother to wait outside. He seemed concerned about what could be asked and answered in front of her. Sendhil's mother acquiesced, gently closing the door behind her.

As soon as she had exited, Vijay turned to Sendhil and began firing questions at him about what was wrong and why he had stopped taking his medications. Sendhil, however, remained silent and maintained his eye contact with the blank wall in front of him. 
Instead, it was Sendhil's brother Selvan who answered. Selvan explained that Sendhil would leave the house in the morning, as if going out to work. But just a few hours later, Sendhil would return home drunk. He would spend the rest of the day sleeping. When Sendhil was not sleeping or "hitting water" (that is, drinking alcohol), he lingered around the house, not working, not doing much of anything. Worry creasing his face, Selvan also reported that Sendhil continued to experience occasional "fits" or seizures.

In spite of these concerns, and in spite of Sendhil's silence, Vijay assured Selvan that Sendhil was "almost normal" now. It was a miracle that he had survived at all, he added. Later, after Sendhil and his family had left, Vijay explained to me that Sendhil had been admitted to the hospital about six months earlier, just prior to my own arrival. He had been very ill and was eventually diagnosed with tuberculous meningitis. This meant that the bacteria that cause tuberculosis had infected the protective membrane surrounding Sendhil's brain and spinal cord, leading to severe inflammation. His weakened immune system had been unable to keep the infection in check.

In general, tuberculous meningitis is exceedingly difficult to diagnose and treat, particularly when specialists and certain kinds of medical equipment are in short supply. A few weeks earlier, I had observed a middle-aged man in a coma admitted into the inpatient ward. Vijay had performed a lumbar puncture to collect cerebrospinal fluid. Even before receiving the results of the laboratory tests, he felt certain that the man was suffering from tuberculous meningitis. Vijay had debated whether to invite a neurologist from a nearby hospital for a consultation, but he believed the comatose man to already be in a late stage of disease. Many of the neurologists and other specialists whom he had previously called on were extremely hesitant to work with HIV-positive patients. With this in mind, Vijay only asked for consultations when he thought that something might be done for the patient. In this particular case, Vijay had decided that it was too late. Almost as if to confirm the wisdom of his decision, the comatose man died the next morning.

But Sendhil's case had been different. After a few weeks of intensive treatment and monitoring in the inpatient ward, he had been pronounced clear of the tuberculosis infection and allowed to return home. Since this near fatal episode, Sendhil's health had improved remarkably. In the weeks and months following Sendhil's hospitalization, there had been no discernible trace of tuberculosis. With the addition of antiretroviral drugs, his viral levels had dropped dramatically. The 
combined forces of these pathological microbes had been, at least momentarily, held at bay.

Soaking in Sendhil's silence, Vijay gestured toward the hefty patient file sitting on the desk in front of him, seemingly to indicate how much work had been involved in keeping Sendhil alive. Admission and discharge records, counseling reports, drug regimens, clinical observations, laboratory results, and referrals populated this record of Sendhil's medical history, in stark contrast to Vasudevan's meager file. For Vijay, Sendhil's patient file was also a history of labor, of expensive drugs and scarce time devoted to the work of preserving a life: a record of his own commitment to keeping Sendhil alive.

Vijay turned toward Sendhil and repeatedly asked him why he was not taking his medications, but it was his brother Selvan who responded over and over again: "He won't tell me why; he just drinks."

Taking a deep breath, Vijay launched into a kind of homily: "Your life is in your hands. We've put in all of this work for you," he said. "Now, you must do something, keep yourself busy: play table tennis, badminton, get a job, anything at all. Keep yourself busy instead of lying around at home.”

In his Pensées, Blaise Pascal (1995, 247; emphasis added) asks: "Who ever proved that it will dawn tomorrow . . . ?"He proceeds to answer his own question: "It is, then, custom which persuades us of it." It is precisely this dawn, which I take to be the fact of living on, that was at stake in Vijay's office. Sendhil did not need to survive so that he might enjoy the pleasures of racket sports. Rather, he needed to do these things, to do "anything at all," as Vijay put it, in order to survive. For Vijay, it was through submitting to the customs of the kingdom of the well-however small in themselves - that Sendhil might once again be inclined toward life. Once again, HIV was submerged into an everyday life structured by ordinary activities. Here, the goal was to furnish Sendhil with a livable subjectivity, but such a remaking was not attempted primarily through the clinical demand of committing to therapy. Vijay's request was that Sendhil pray or play, do anything at all, to regain a grasp on life. Rather than biological survival grounding the possibility of social life, in Vijay's framing it was social life that made possible biological survival (cf. Butler 2004, 39).

Although Sendhil had gradually turned toward Vijay, he remained silent, avoiding the doctor's eyes while searching for a safe spot to train his vision between the doctor's chin and the clinic floor. It was impossible for me to say whether Vijay's admonitions had moved him. 
But Sendhil's silence did not deter Vijay. "Listen: if something happens to you, your brother will be sad for some time, but he'll be fine again after a while. Your father will be sad too, but he will also be fine."

"Your mother," he began, "and mothers are different from fathers, your mother will be heartbroken. She'll never recover. I've seen that your mother accompanies you on every visit to the hospital. Just think of how lucky you are. Listen: we all have problems. Some seem worse than others, but all are relative. We must learn to live with it."

Despite her exile from the examination room, Sendhil's mother was reincorporated as a critical figure in Vijay's address. She was the one who accompanied Sendhil to the hospital each time. She was the one who waited for him just outside. These simple acts of accompaniment constituted the kind of tacit ethics demonstrated through the "minutest of gestures" (Das 2012, 135). Although the physical presence of Sendhil's mother had been limited to the first minutes of the clinical encounter, her presumed desire for her son to live was very much present, articulated through the doctor's speech.

Here, Vijay had rendered explicit the generally unarticulated forms of care provided by Sendhil's mother into his argument. It was in the name of his mother that Vijay called on Sendhil to live: she'll never recover. For Vijay, such a claim could not have been articulated from the position of just any kin relation. The generic trope of the dutiful and doting mother, while arguably pan-Indic, has a particularly strong hold in the state of Tamil Nadu, through such figures as Tamil Thai (Mother Tamil) and the recently deceased chief minister Jayalalitha, commonly referred to as Amma, or mother (Trawick 1992; Ramaswamy 1997). This genericity is present in Vijay's claim that brothers and fathers could recover, but mothers would remain heartbroken, because "mothers are different from fathers." ${ }^{14}$ At the same time, Vijay invoked the singularity of Sendhil's mother; she was the one who accompanied him to the hospital every time. Sendhil's mother is a token of a general type: motherhood, Indian motherhood or, perhaps more specifically, Tamil motherhood. At the same time, she is irrepressibly singular, as Sendhil's mother, as the one who accompanies him, as the one who will never recover.

Indeed, such kin-based commitments might also be productively related to older Tamil ethical traditions frequently articulated in terms of concrete familial ties. For example, a particularly damning couplet from the sixth-century Thirukkural notes that a drunkard's glee brings suffering primarily to his mother. Vijay might not have consciously intended to invoke this stanza in singling out the 
relationship between Sendhil's nonadherence to therapy (which included his drinking) and his mother's suffering. Yet as Anand Pandian (2008) has convincingly argued, these older ethical traditions continue to suffuse Tamil life (and familial relations) in the present, albeit in fragmentary form and perhaps most often in the absence of explicit citation.

Although Vijay began by repeatedly asking Sendhil why he would not take his medication, Sendhil's silence forced him to adopt a different tack. Rather than continuing to insist on the ethical priority of the commitment to therapy, Vijay instead invoked another commitment structured by a form of maternal care that was generic and yet painfully specific. In so doing, Vijay did not abandon his investment in medication altogether. Rather, returning to treatment became a means to an end: here, to prevent Sendhil's mother's unending heartbreak. Vijay proposed that Sendhil's primary commitment was to his mother, a commitment that hierarchically subsumed his commitment to therapy. For his mother, if not for himself, he must live, and to live, he must recommit himself to treatment, and to the minor customs that composed a life.

Having already spent more time with Sendhil and his family than he did with most of his patients, Vijay hastily scratched a list of drugs on his prescription pad. He tore out the page and handed it to Selvan. The two brothers left, Sendhil never having said a word.

\section{COMMITMENTS THAT ARE NOT ONLY ONE'S OWN}

Both within the clinic and beyond it, everyday life is shot through by a variety of commitments. Although many of these commitments are found to be congruent, even unremarkably so, others might be experienced as mutually exclusive. Such conflict demands a response, not only from the subject who is pulled on from many directions but also from those caught in the often extensive webs that spin out from such commitments. In the clinical encounters I have described in this essay, doctors and counselors were drawn into reasoned engagements with patients and their families as they navigated these ethically complex terrains. At stake were not only life and death but also the fulfillment of hierarchically superior commitments to close kin.

In attending to those ordinary moments when commitments are felt to be at odds, we can develop a better understanding of the particular styles of reasoning that people employ to manage conflictual situations that refuse the kind of tacitness that scholars have associated with everyday ethical life. In the scenes I have discussed above, the congruence of commitments was not established in advance. 
Rather, congruence was attempted through a particular style of ethical reasoning that I have described in terms of hierarchical subsumption.

The cases of Sendhil and Vasudevan present very different interpretive challenges. In the end, I cannot tell you what Sendhil wanted, what his silence meant. Nor do I know whether Vasudevan managed to find a way to settle his daughter while continuing his treatment. Instead, what I have focused on in this essay is a specific style of ethical reasoning that I observed in these clinical encounters, through which the relationship between commitments to therapy and close kin was actively reconfigured.

Both Sendhil's silence and Vasudevan's speech compelled the staff at the clinic to consider not only the relationship between such commitments but also to elaborate what might be involved in fulfilling them. In both cases, survivaland the commitment to therapy — was proposed as a means to what was recognized as a superior end. Notably, such reasoning did not constitute a private act. Indeed, it was only through the engagement of clinicians, counselors, patients, and their families that a momentary priority could be established, one in which therapeutic adherence was hierarchically subsumed by specific familial commitments. Whether or not these other commitments were genuinely felt or invoked as tactics of persuasion, the staff at the clinic critically came to articulate the commitment to therapy as subordinate yet necessary to the fulfillment of specific commitments to close kin.

Paradoxically, their willingness to engage from the position of their patients, for whom survival was not necessarily of primary import, made possible a creative reordering in which therapeutic adherence could continue to matter: not simply because treatment made survival possible, but also because living on was figured as a necessary condition to the fulfillment of ethically prioritized commitments to specific kin. The hierarchies I have described were emergent phenomena, the products of an ethical reasoning that became possible when the clinic was opened to other forms of commitment in which patients never figured simply as patients, but as sons and fathers as well. The demands posed by these other commitments, although addressed primarily to the patients, also required Vijay and Prabhakar to engage in the work of ethical reasoning. In the conversations I have discussed, the relative valuations of both kinship and survival were, at least in part, shared between clinical staff and patients. If patients could be fathers and sons, so too could doctors and counselors. In this sense, perhaps these other commitments were also theirs. 


\begin{abstract}
What shape does ethical reasoning assume in the face of potentially contradictory commitments? Drawing on fieldwork in a private clinic in Chennai, the capital of the South Indian state of Tamil Nadu, I examine how patients, their families, and the clinic's staff navigated ethically complex situations in which one was called on as both family member and patient. I argue that the doctors and counselors at the clinic attempted to reconfigure the relationship between what were experienced as divergent or contradictory commitments - to treatment and to close kin - in terms of what I call hierarchical subsumption. This mode of response worked not simply to recast treatment as noncontradictory with familial obligations; rather, the commitment to therapy became hierarchically subsumed by and therefore necessary to the fulfillment of such kin-based commitments. In attending to those ordinary moments in which commitments are felt to be at odds, I suggest that we might develop a better understanding of the particular styles of ethical reasoning that people employ to manage such conflictual situations, which refuse the kind of tacitness that scholars have associated with everyday life. [anthropology of ethics; styles of ethical reasoning; hierarchical subsumption; commitment; therapy; kinship; HIV/AIDS; India]
\end{abstract}

\title{
NOTES
}

Acknowledgments My deepest gratitude to Mara Green, Aniruddhan Vasudevan, T. R. P. Kesan, Laurence Tessier, Anthony Stavrianakis, Lawrence Cohen, Mareike Winchell, Janelle Lamoreaux, Ruth Goldstein, Emily Chua, Patricia Kubala, Stefania Pandolfo, João Biehl, Naisargi Dave, Sophia Powers, Greer Waldrop, Michele Friedner, and Jonathan Yamakami, who have all in various forms encouraged me to persist in the revision of this essay since its first drafting in 2011. My thanks for the helpful comments and suggestions from audiences at the South Asia by the Bay Conference at Stanford University and the Tamil Studies Conference at the University of California, Berkeley, in particular Anjali Arondekar, Dolly Kikon, and Sharika Thiranagama. I would also like to express my thanks to the anonymous reviewers for their incisive yet supportive critique, as well as to the editors at Cultural Anthropology, in particular James Faubion, for pushing me to engage more deeply with recent work on the anthropology of ethics. Research and writing were supported by the Wenner-Gren Foundation, the Social Science Research Council, the Charlotte W. Newcombe Foundation, the University of California, and Princeton University's Program in Global Health. Finally, my thanks to the doctors, counselors, patients, and their families in Chennai for sharing with me their various and complex commitments.

1. Names and identifying markers have been modified to preserve anonymity. The ethnographic material draws on notes written during or immediately after the events in question. All conversations took place in either Tamil or English. Translations are my own.

2. This dialectical mode of reasoning, simultaneously intellectual and ethical, closely resembles what Louis Dumont $(1980,240)$ famously described in terms of the "encompassing of the contrary." However, it is important to note that Dumont generally thought about hierarchy in terms of the relationship between caste groups, and social strata more generally, whereas I am retooling his concept to think about the relationship between ethical commitments. Unlike Dumont, I make no claims about an Indic or even a Tamil holism. I am indebted here to Joel Robbins (2007, 2012a), whose rehabilitation of Dumont's work on hierarchy and the prioritization of specific values over others informs my own thinking about ethical reasoning. As Robbins (2012b) notes, "Ever since Ar- 
istotle, the tendency within virtue ethics has been to imagine that the various virtues one ought to cultivate work well together. . . . This means a life well lived need not feature too many hard decisions and tragic choices between competing goods. But there is clearly room for the anthropology of ethics also to constitute itself as an ethics of decision making."

3. Many anthropologists working to systemize the study of ethics in anthropology have developed similar schemas in which ethical life is divided between two registers (e.g., Faubion 2011; Laidlaw 2014; Robbins 2009, 2012a, 2012b; Zigon 2007, 2009, 2014). Each, however, envisions this division somewhat differently, occasioning a set of helpful debates. For two examples relevant to this essay, see James Faubion's $(2011,20)$ critique that Jarrett Zigon draws too stark of a line between these two registers, and in the process evacuates from the ordinary the possibility of reflection. For his part, Zigon (2014) argues that Michael Lambek and Veena Das smuggle the baggage of transcendental philosophy into the ordinary, despite their own claims to the contrary.

4. In his discussion of ethical complexity, James Faubion $(2011,66)$ points out that "certain subject positions might be the necessary or the sufficient condition of certain others to which they are nevertheless not equivalent." He further notes that "certain subject positions include or can include or permit the nesting within of certain others." In Faubion's terms, my focus in this essay is on how a specific commitment might be granted ethical priority such that subsidiary yet necessary commitments can be nested within it.

5. We might think in particular of Saba Mahmood's (2005) ethnography of the Islamic da'wa movement among Egyptian women, in which ethical life does not entail simply acceding to norms without reflection, but rather involves determining how one might come to inhabit a norm in a particular way. Along similar lines, James Faubion (2011, 65) points out that one might be a prodigal son or a good son. The difference is not one of subject position, but rather of the way in which one comes to occupy the same position. It is clear that the existence of norms does not provide ready-made answers to the question of "what counts as living up to being a subject of one or another quality of kind" (Faubion 2011, 4).

6. Here, my research echoes the findings of many medical anthropologists who have demonstrated that survival is not always the highest priority, neither for HIV-positive patients nor for caregivers, albeit for a variety of different reasons (see Biehl 2007; Nguyen 2010; Ticktin 2011, 192; Whyte et al. 2013; Smith 2014).

7. I draw this idea of suspension from Søren Kierkegaard (1985), who famously describes how the suspension of the ethical opens up the possibility for Abraham to heed a contradictory calling.

8. The idea of the biomoral comes from the work of McKim Marriott (1976), who, inspired by David Schneider's work on kinship, wrote of the simultaneously biological and moral substance that composes the Indian dividual. Although this idea has been creatively developed by many anthropologists, far beyond those who work on questions of medicine and personhood in South Asia, we might nonetheless think in particular of Joseph Alter's $(1996,301)$ extensive scholarship on Gandhian dietetics, in which morality was a problem in which "truth and biology were equally implicated." At the same time, it is important to note the ways in which both antistigma activists and those involved in the anti-Brahmin/anticaste movements in South India have worked to pry apart ideas of morality and biology, under the signs of political and scientific modernity, bhakti devotional movements, and the Tamil Self-Respect Movement (suya mariyathai iyakkam).

9. However, adherence and nonadherence have a much longer history as critical terms in the public health vocabulary, stretching back at least as far as the early 1950s, with the introduction of long-term chemotherapy for tuberculosis (Venkat 2016).

10. Although counselors and nurses often spoke of noi ethirppu sakthi, doctors preferred communicating in terms of CD4 count, an enumeration of the number of CD4 white 
blood cells in a cubic millimeter of blood. For the clinicians, this number indicated whether treatment was effective or failing.

11. See the work of Harris Solomon (2016) on the incorporation of diabetes care into everyday routines in India.

12. Vasudevan's request immediately brought to mind what was then a recently decided Supreme Court case. The newspapers had carried daily coverage of the case, and television pundits regularly expounded their views on the theological, medical, and legal issues at stake. The case itself involved a nurse from the South Indian state of Karnataka, Aruna Shanbaug, who had been working in the King Edward Memorial Hospital in Bombay. In 1973, Shanbaug had been raped and beaten by a ward boy (a term used to refer to male hospital staff who clean the floors, change sheets, and perform other services in the hospital), putting her into a vegetative state. She became a patient in the same hospital where she had worked, cared for by her fellow nurses.

In 2010, the journalist Pinki Virani filed a plea for euthanasia on behalf of Shanbaug to the Indian Supreme Court. The court's landmark judgment stated that passive euthanasia was acceptable under certain strictly defined conditions. However, Virani's petition was denied on the grounds that the nursing staff at the hospital who cared for Shanbaug were her real family and wanted her to live. Although the principle of euthanasia had been affirmed, the court ruled that Virani lacked standing in comparison to this surrogate family of nurses. In the court's own ruling, the nurses' commitment to Shanbaug outweighed the court's principled commitment to the right to die. For the sake of her nonbiological family, Shanbaug was made to live. I do not know whether Vasudevan had the Shanbaug case in mind when he made his plea to Prabhakar, but the timing of his request and the ubiquity of the case in the media made it unlikely he was unaware of the ruling.

It also bears mentioning that the specific means by which Prabhakar asked to dieusi or injection - enjoys extreme popularity as a therapeutic modality throughout India (van der Geest 1982; Nichter 1989; Whyte, van der Geest, and Hardon 2002). However, what was unique about Vasudevan's plea was that the heightened healing potential of the injection had been reversed, transforming a therapeutic modality into a means of death. Interestingly, the Tamil word marunthu - much like the Greek pharmakon - is generally used to refer to medicine, but in slightly modified forms it can refer to pesticide, insecticide, poison, or magic used to cause illness in humans. Vasudevan's entreaty extended this ambiguity to the injection, as a particularly potent form of marunthu.

13. Critically, such concepts have been powerfully resignified in various moments - for example, kadamai in the later Sangam literature refers to the duties or taxes paid to the king. In the modern era, kadamai was refigured as part of the anticaste Self-Respect Movement in South India, which gave rise to the massively popular slogan kadamai, kanniam, kattupaadu (roughly, duty, dignity, and discipline or control). As such, it is important to keep in mind how such concepts operate with different valences within and between caste-based groups, and how such concepts undergo subtle mutations in light of broader socioeconomic and political transformations.

14. In subsuming therapeutic adherence under the hierarchically superior commitment to one's mother, Prabhakar's way of caring might be understood as generic, but not for that reason anonymous, an important distinction in light of Lisa Stevenson's (2014) characterization of the mode of care common to colonial and postcolonial regimes in her powerful study of suicide and tuberculosis epidemics in the Canadian Arctic. In fact, Stevenson's work would suggest that anonymity emerges through an inverse style of reasoning, in which the therapeutic (or biopolitical) mandate occupies an ethically superior position and hierarchically subsumes commitments to kin. 


\section{REFERENCES}

Alter, Joseph S.

1996 "Gandhi's Body, Gandhi's Truth: Nonviolence and the Biomoral Imperative of Public Health.” Journal of Asian Studies 55, no. 2: 301-22. https://doi.org/ 10.2307/2943361.

Biehl, João

2007 Will to Live: AIDS Therapies and the Politics of Survival. Princeton, N.J.: Princeton University Press.

Brada, Betsey Behr

2013 "How to Do Things to Children with Words: Language, Ritual, and Apocalypse in Pediatric HIV Treatment in Botswana." American Ethnologist 40, no. 3: 437-

Butler, Judith 51. https://doi.org/10.1111/amet.12031.

2004 Undoing Gender. New York: Routledge.

Canguilhem, Georges

1989 The Normal and the Pathological. Translated by Carolyn R. Fawcett, in collaboration with Robert S. Cohen. New York: Zone Books. Originally published in 1966.

Clark-Decès, Isabelle

2014 The Right Spouse: Preferential Marriages in Tamil Nadu. Stanford, Calif.: Stanford University Press.

Cohen, Lawrence

2001 "The Other Kidney: Biopolitics Beyond Recognition." Body and Society 7, nos. 2-3: 9-29. https://doi.org/10.1177/1357034X0100700202.

2013 "Given Over to Demand: Excorporation as Commitment." Contemporary South Asia 21, no. 3: 318-32. https://doi.org/10.1080/09584935.2013.826630.

Das, Veena

2012 “Ordinary Ethics." In A Companion to Moral Anthropology, edited by Didier Fassin, 139-49. Malden, Mass.: Wiley.

2015 Affliction: Health, Disease, Poverty. New York: Fordham University Press.

Diamond-Smith, Nadia, Nancy Luke, and Stephen McGarvey

2008 “'Too many girls, too much dowry': Son Preference and Daughter Aversion in Rural Tamil Nadu, India." Culture, Health, and Sexuality 10, no. 7: 697-708. https://doi.org/10.1080/13691050802061665.

Dube, Siddharth

2000 Sex, Lies, and AIDS. New Delhi: HarperCollins India.

Dumont, Louis

1980 Homo Hierarchicus: The Caste System and Its Implications. Translated by Mark Sainsbury, Louis Dumont, and Basia Gulati. Chicago: University of Chicago Press. Originally published in 1966.

1986 A South Indian Subcaste: Social Organization and Religion of the Pramalai Kallar. Translated by Michael Moffatt, Lewis Morton, and Alice Morton. Delhi: Oxford Faubion, James D.

University Press. Originally published in 1957.

2011 An Anthropology of Ethics. New York: Cambridge University Press.

Howell, Signe

1997 "Introduction.” In The Ethnography of Moralities, edited by Signe Howell, 1-21.

Keane, Webb New York: Routledge.

2010 "Minds, Surfaces, and Reasons in the Anthropology of Ethics." In Ordinary Ethics: Anthropology, Language, and Action, edited by Michael Lambek, 64-83. New York:

Kierkegaard, Søren Fordham University Press.

1985 Fear and Trembling. Translated by Alastair Hannay. New York: Penguin. Originally published in 1843 . 
Laidlaw, James

2014 The Subject of Virtue: An Anthropology of Ethics and Freedom. New York: Cambridge University Press.

Lambek, Michael

2010 "Introduction." In Ordinary Ethics: Anthropology, Language, and Action, edited by Michael Lambek, 1-36. New York: Fordham University Press.

Mahajan, Manjari

2008 "The Politics of Public Health Emergencies: AIDS Epidemics in India and South Africa." PhD dissertation, Cornell University.

Mahmood, Saba

2005 Politics of Piety: The Islamic Revival and the Feminist Subject. Princeton, N.J.: Princeton University Press.

Marriott, McKim

1976 "Hindu Transactions." In Transactions and Meaning: Directions in the Anthropology of Exchange and Symbolic Behavior, edited by Bruce Kapferer, 109-42. Philadelphia: Institute for the Study of Human Issues.

Nguyen, Vinh-Kim

2010 The Republic of Therapy: Triage and Sovereignty in West Africa's Time of AIDS. Durham, N.C.: Duke University Press.

Nichter, Mark

1989 "Paying for What Ails You: Sociocultural Issues Influencing the Ways and Means of Therapy." In Anthropology and International Health: South Asian Case Studies, 214 32. Dordrecht, Netherlands: Kluwer Academic.

Pandian, Anand

2008 "Tradition in Fragments: Inherited Forms and Fractures in the Ethics of South India." American Ethnologist 35, no. 3: 466-80. https://doi.org/10.1111/j.15481425.2008.00048.x.

Pandolfo, Stefania

2007 “'The Burning': Finitude and the Politico-Theological Imagination of Illegal Migration.” Anthropological Theory 7, no. 3: 329-63. https://doi.org/10.1177/ 1463499607080194.

Pascal, Blaise

1995 Pensées. Translated by A. J. Krailsheimer. New York: Penguin. Originally published in 1669-1670.

Pinto, Sarah

2014 Daughters of Parvati: Women and Madness in Contemporary India. Philadelphia: University of Pennsylvania Press.

Ramaswamy, Sumathi

1997 Passions of the Tongue: Language Devotion in Tamil India, 1891-1970. Berkeley:

Robbins, Joel University of California Press.

2007 "Between Reproduction and Freedom: Morality, Value, and Radical Cultural Change." Ethnos 72, no. 3: 293-314. https://doi.org/10.1080/ 00141840701576919.

2009 "Value, Structure, and the Range of Possibilities: A Response to Zigon." Ethnos 74, no. 2: 277-85. https://doi.org/10.1080/00141840902940500.

2012a “Cultural Values.” In A Companion to Moral Anthropology, edited by Didier Fassin, 117-32. Malden, Mass.: Wiley.

2012b "On Becoming Ethical Subjects: Freedom, Constraint, and the Anthropology of Morality." Anthropology of This Century, no. 5. http://aotcpress.com/articles/

Smith, Daniel Jordan ethical-subjects-freedom-constraint-anthropology-morality.

2014 AIDS Doesn't Show Its Face: Inequality, Morality, and Social Change in Nigeria. Chicago: University of Chicago Press. 
Solomon, Harris

2016 Metabolic Living: Food, Fat, and the Absorption of Illness in India. Durham, N.C.: Duke University Press.

Sontag, Susan

1990 Illness as Metaphor and AIDS and its Metaphors. New York: Farrar, Straus, and Giroux.

Stevenson, Lisa

2014 Life Beside Itself: Imagining Care in the Canadian Arctic. Berkeley: University of California Press.

Sykes, Karen

2009 "Residence: Moral Reasoning in a Common Place_Paradoxes of a Global Age." In Ethnographies of Moral Reasoning: Living Paradoxes of a Global Age, edited by

Ticktin, Miriam I. Karen Sykes, 3-40. New York: Palgrave Macmillan.

2011 Casualties of Care: Immigration and the Politics of Humanitarianism in France. Berkeley: University of California Press.

Trawick, Margaret

1992 Notes on Love in a Tamil Family. Berkeley: University of California Press.

van der Geest, Sjaak

1982 "The Illegal Distribution of Western Medicines in Developing Countries: Pharmacists, Drug Pedlars, Injection Doctors, and Others. A Bibliographic Exploration.” Medical Anthropology 6, no. 4: 197-219. https://doi.org/ 10.1080/01459740.1982.9987019.

Van Hollen, Cecilia

2013 Birth in the Age of AIDS: Women, Reproduction, and HIV/AIDS in India. Stanford, Calif.: Stanford University Press.

Venkat, Bharat Jayram

2016 “Cures.” Public Culture 28, no. 3: 475-97. https://doi.org/10.1215/089923633511502.

Whyte, Susan Reynolds, Sjaak van der Geest, and Anita Hardon

2002 Social Lives of Medicines. New York: Cambridge University Press.

Whyte, Susan Reynolds, Michael Whyte, Lotte Meinert, and Jenipher Twebaze

2013 "Therapeutic Clientship: Belonging in Uganda's Projectified Landscape of AIDS Care." In When People Come First: Critical Studies in Global Health, edited by João Zigon, Jarrett Biehl and Adriana Petryna, 140-65. Princeton, N.J.: Princeton University Press.

2007 "Moral Breakdown and the Ethical Demand: A Theoretical Framework for an Anthropology of Moralities." Anthropological Theory 7, no. 2: 131-50. https:// doi.org/10.1177/1463499607077295.

2009 "Within a Range of Possibilities: Morality and Ethics in Social Life." Ethnos 74, no. 2: 251-76. https://doi.org/10.1080/00141840902940492.

2014 "An Ethics of Dwelling and a Politics of World-Building: A Critical Response to Ordinary Ethics." Journal of the Royal Anthropological Institute 20, no. 4: 746 64. https://doi.org/10.1111/1467-9655.12133. 